\title{
ogopaedica
ogziensia
}

$\mathrm{Nr} 2$ (2018)

DOl: http://dx.doi.org/10.18778/2544-7238.02.15

\section{Informacje zarządu Łódzkiego Oddziału PTL}

W dniu 25 maja 2018 roku odbyło się Walne Zebranie członków Łódzkiego Oddziału Polskiego Towarzystwa Logopedycznego, na którym wybrano nowy zarząd w następującym składzie:

- przewodnicząca: prof. nadzw. UŁ dr hab. Renata Marciniak-Firadza,

- I wiceprzewodnicząca: dr Ewa Gacka,

- II wiceprzewodniczący: mgr Mateusz Szurek,

- skarbnik: mgr Paulina Żatkiewicz,

- sekretarz: dr Ewelina Zając.

Dokonano także wyboru Komisji Rewizyjnej, w skład której weszły: prof. nadzw. UŁ dr hab. Irena Jaros, dr Izabela Ejsmunt-Wieczorek, dr Monika Kaźmierczak.

Siedziba oddziału mieści się w budynku Wydziału Filologicznego Uniwersytetu Łódzkiego w Zakładzie Dialektologii Polskiej i Logopedii. Głównym celem działalności będzie integracja łódzkiego środowiska logopedycznego, a także organizacja warsztatów, szkoleń, wykładów i seminariów, na których można będzie zdobyć praktyczne umiejętności oraz wymienić się doświadczeniami zawodowymi.

Pierwsze powyborcze zebranie Łódzkiego Oddziału PTL odbyło się 13 czerwca 2018 roku. Tematem spotkania było zaprezentowanie projektu działalności towarzystwa w roku akademickim 2018/2019 oraz szkolenie pt. RODO w gabinecie logopedycznym, przeprowadzone przez mgra Zbigniewa Firadzę. Zapoznał on uczestników z rozporządzeniem dotyczącym ochrony danych osobowych, przekładając przepisy na praktyczne wskazówki dla logopedów prowadzących gabinety logopedyczne oraz pracujących w innych placówkach.

Zarząd Łódzkiego Oddziału PTL nawiązał także współpracę z Łódzkim Oddziałem Polskiego Związku Logopedów.

Przy współpracy z Łódzkim Oddziałem PTL Zakład Dialektologii Polskiej i Logopedii Uniwersytetu Łódzkiego 22 września 2018 roku zorganizował III Łódzkie 
Seminarium Logopedyczne pt. Diagnoza i terapia osób dorostych z zaburzeniami mowy, na które zaprosił wszystkich członków oddziału.

W najbliższym czasie planowane są cykliczne zebrania oddziału, podczas których omawiane będą sprawy bieżące i nadchodzące wydarzenia.

mgr Mateusz Szurek wiceprzewodniczącyŁódzkiego Oddziału PTL 